\title{
Acute Bilateral External Ophthalmoplegia in Miller Fisher Syndrome
}

\author{
(D) Feyza Calis Karanfil, ${ }^{1}$ (D) Huban Atilla ${ }^{2}$ \\ ${ }^{1}$ Department of Ophthalmology, Yuksek Ihtisas University, Ankara, Turkey \\ ${ }^{2}$ Department of Ophtalmology, Ankara University, Ankara, Turkey
}

\begin{abstract}
Miller Fischer syndrome is a rare entity characterized by the triad of external ophthalmoplegia, ataxia, and areflexia. It is thought to be a form of Guillain-Barre syndrome. Presently described is the case of a 68-year-old woman who presented with bilateral, external ophthalmoplegia, areflexia, and ataxia. After excluding other conditions, a diagnosis of Miller Fisher syndrome was made. She was treated with intravenous immunoglobulin and completely recovered in 8 weeks.

Keywords: External ophthalmoplegia, intravenous immunoglobulin, Miller Fisher syndrome.
\end{abstract}

\section{Introduction}

Miller Fischer syndrome (MFS) was first described by Collier in 1932. This rare entity is considered to be a variant form of Guillain-Barre syndrome (GBS), characterized by a triad of external ophthalmoplegia, ataxia, and areflexia (I). MFS usually occurs in the fourth or fifth decade of life (2). In twothirds of the cases, there is a history of viral infection within 2 weeks of development (2). The most frequently responsible viral agents are the Epstein-Barr virus, mumps virus, measles virus, echovirus, coxsackievirus, influenza virus, and the cytomegalovirus (2). Although the diagnosis of the disease is based on clinical findings, some laboratory tests will support the diagnosis. Some $85 \%$ to $90 \%$ of patients with MFS test positive for the ganglioside (GQIb) antibody, and MFS is strongly associated with oculomotor nerve lesions. Lumbar puncture and cerebral spinal fluid (CSF) analysis of patients has generally revealed albumin cytologic dissociation. The prognosis of the disease is good; usually complete recovery is seen in 8 to 10 weeks (2-7). Plasmapheresis, in- travenous immunoglobulin, and high-dose steroids are the current treatment options. This report is a description of the case of a 68-year-old woman who presented with bilateral external ophthalmoplegia. Informed consent was obtained from the patient for this study.

\section{Case Report}

A 68-year-old woman presented at the Ankara University strabismus department with a complaint of diplopia and truncal unsteadiness ongoing for 3 weeks. Her history included hypertension and diabetes mellitus controlled with medical treatment. There was no recent history of infection. An ophthalmic examination yielded a best corrected visual acuity of $8 / 10$ bilaterally. Color vision tested with Ishihara plates was normal. Both pupils were isochoric with a sluggish response to light and accommodation. There was no relative afferent pupillary defect. An eye movement test revealed a bilateral -4 reduction in all directions of gaze. The patient also had mild ptosis and grade 2 nuclear sclerosis in both

Address for correspondence: Feyza Calis Karanfil, MD. Yuksek Ihtisas Universitesi, Oftalmoloji Anabilim Dali, Ankara, Turkey

Phone: +90 5304333071 E-mail: feyzacalis@gmail.com

Submitted Date: February 16, 2019 Accepted Date: May 09, 2019 Available Online Date: August 05, 2019

${ }^{\circ}$ Copyright 2019 by Beyoglu Eye Training and Research Hospital - Available online at www.beyoglueye.com OPEN ACCESS This work is licensed under a Creative Commons Attribution-NonCommercial 4.0 International License. 
eyes. A fundoscopic examination indicated grade 3 hypertensive retinopathy bilaterally.

A cranial and orbital magnetic resonance imaging (MRI) scan did not reveal any abnormalities. Laboratory tests of complete blood count, complete biochemical profile, thyroid function, lipid profile, inflammatory markers, and vitamin BI 2 blood levels were all normal.

Based on clinical findings, a diagnosis of MFS was suspected. The patient was referred to the neurology clinic. A neurological examination indicated that reflex responses were absent, and ataxia was confirmed. A cerebrospinal fluid (CSF) examination revealed increased protein levels, no white cells, and no organisms were cultured. A diagnosis of MFS was confirmed based on the clinical manifestations and CSF albumin cytological dissociation.

Treatment with $0.4 \mathrm{~g} / \mathrm{kg} /$ day intravenous immunoglobulin for 5 days was initiated and the patient had a complete recovery in 8 weeks.

\section{Conclusion}

MFS is a rare, acute, autoimmune polyneuropathy (I). It is a rare variant of GBS, typically presenting as ophthalmoplegia with areflexia and ataxia $(I, 2)$. Our patient was diagnosed with MFS according to the diagnostic criteria. All of the components of the classic triad of MFS are not always present, and there may be overlap with GBS (3). Mydriasis, which indicates denervation hypersensitivity with or without light near dissociation, may not always be present (4). Our patient did not exhibit mydriasis, but there was a sluggish response to light.

The pathogenesis of MFS is immunological. Most cases are a result of antibodies attacking the myelin sheath of peripheral nerves; occasionally, the axon is the primary target (5). Recent research has shown that MFS is very strongly associated with antibodies to ganglioside (GQIb), a component of myelin (6). Over $90 \%$ of patients with MFS have these antibodies. Molecular mimicry is the most likely mechanism of the immunological reaction (5). Some infectious agents, such as Campylobacter jejuni, Haemophilus influenzae, have an epitope that is similar to that of the myelin sheath, which can activate immunological cross-reaction $(5,7)$. Most MFS patients have a preceding respiratory tract infection. Our patient did not appear to have any recent history of infection. The disease usually progresses for $I$ to 2 weeks before stabilizing and steadily improving; however, it may continue for as long as 4 weeks (8). The prognosis is generally excellent. Most patients completely recover within 2 to 3 months, though a small number have mild residual ataxia; diplopia and ptosis almost always completely resolve $(2,8,9)$.

There is no consensus concerning immunomodulatory treatment for MFS, largely because there have been no con- trolled, randomized, therapeutic trials. Some studies have demonstrated a benefit from the use of plasmapheresis in the treatment of MFS; however, other studies have had different results, making it controversial (10-12). Intravenous immunoglobulin has been shown to slightly shorten the interval between ophthalmoplegia and ataxia onset and the beginning of the alleviation of symptoms (13). Our patient had a complete recovery in 8 weeks with intravenous immunoglobulin therapy.

Generally, ophthalmologists are the first physicians to see these patients, and therefore, they must be familiar with MFS. A detailed history and a demonstration of bilaterality of symptoms accompanying neurological findings such as areflexi-ataxi with a normal cranial MRI scan are key factors in the diagnosis. A subsequent referral to a neurologist is very important because there is a risk of progression to GBS.

\section{Disclosures}

Informed consent: Written informed consent was obtained from the patient for the publication of the case report and the accompanying images.

Peer-review: Externally peer-reviewed.

Conflict of Interest: None declared.

Authorship Contributions: Involved in design and conduct of the study (FÇK, HA); preparation and review of the study (FÇK, $\mathrm{HA}$ ); data collection (FÇK, HA).

\section{References}

I. Fisher M. An unusual variant of acute idiopathic polyneuritis (syndrome of ophthalmoplegia, ataxia and areflexia). N Engl J Med 1956;255:57-65. [CrossRef]

2. Mori M, Kuwabara S, Yuki N. Fisher syndrome: clinical features, immunopathogenesis and management. Expert Rev Neurother 2012;12:39-5I. [CrossRef]

3. Van der Meché FG, Van Doorn PA, Meulstee J, Jennekens FG; GBS-consensus group of the Dutch Neuromuscular Research Support Centre. Diagnostic and classification criteria for the Guillain-Barré syndrome. Eur Neurol 200 I;45:133-9. [CrossRef]

4. Nitta T, Kase M, Shinmei Y, Yoshida K, Chin S, Ohno S. Mydriasis with light-near dissociation in Fisher's Syndrome. Jpn J Ophthalmol 2007;5I:224-7. [CrossRef]

5. Yuki N, Taki T, Takahashi M, Saito K, Yoshino H, Tai T, et al. Molecular mimicry between GQIb ganglioside and lipopolysaccharides of Campylobacter jejuni isolated from patients with Fisher's syndrome. Ann Neurol 1994;36:79I-3. [CrossRef]

6. Chiba A, Kusunoki S, Obata H, Machinami R, Kanazawa I. Serum anti-GQ Ib lgG antibody is associated with ophthalmoplegia in Miller Fisher syndrome and Guillain-Barré syndrome: clinical and immunohistochemical studies. Neurology 1993;43:191 I-7.

7. Uncini $A$, Lugaresi $A$. Fisher syndrome with tetraparesis and antibody to GQIb: evidence for motor nerve terminal block. Muscle Nerve 1999;22:640-4. [CrossRef] 
8. Yuan CL, Wang YJ, Tsai CP. Miller fisher syndrome: a hospitalbased retrospective study. Eur Neurol 2000;44:79-85. [CrossRef]

9. Mori M, Kuwabara S, Fukutake T, Yuki N, Hattori T. Clinical features and prognosis of Miller Fisher syndrome. Neurology 200।;56:I 104-6. [CrossRef]

10. Yeh JH, Chen WH, Chen JR, Chiu HC. Miller Fisher syndrome with central involvement: successful treatment with plasmapheresis. Ther Apher 1999;3:69-7I. [CrossRef]

I I. Mori M, Kuwabara S, Fukutake T, Hattori T. Plasmapheresis and
Miller Fisher syndrome: analysis of 50 consecutive cases. J Neurol Neurosurg Psychiatry 2002;72:680. [CrossRef]

12. Bai HX, Wang ZL, Tan LM, Xiao B, Goldstein JM, Yang L. The effectiveness of immunomodulating treatment on Miller Fisher syndrome: a retrospective analysis of 65 Chinese patients. J Peripher Nerv Syst 2013;18:195-6. [CrossRef]

13. Mori M, Kuwabara S, Fukutake T, Hattori T. Intravenous immunoglobulin therapy for Miller Fisher syndrome. Neurology 2007;68: I |44-6. [CrossRef] 